\title{
Prototype e-Report PAUD 1.0 untuk Menyusun Laporan Perkembangan Anak Usia Dini
}

\author{
Prima Suci Rohmadheny ${ }^{1}{ }^{凶}$, Intan Puspitasari ${ }^{1}$, Miftahurrahma Rosyda $^{2}$, Avanti Vera Risti \\ Pramudyani ${ }^{1}$ \\ Pendidikan Guru Pendidikan Anak Usia Dini, Universitas Ahmad Dahlan, Indonesia(1) \\ Teknik Informatika, Universitas Ahmad Dahlan, Indonesia(2) \\ DOI: $\underline{10.31004 / o b s e s i . v 6 i 4.1643}$
}

\begin{abstract}
Abstrak
Seiring dengan perkembangan teknologi, laporan perkembangan anak disusun dengan menggunakan aplikasi komputer. Namun, kesiapan guru PAUD dalam hal literasi komputer terbatas pada penggunaan Ms. Office (Ms. Word, Ms. Excel, dan Ms. Power Point) secara sederhana. Oleh karena itu, penelitian ini dilakukan untuk merancang prototype laporan perkembangan anak menggunakan Ms.Excel untuk menunjang pekerjaan guru PAUD. Penelitian dilakukan dengan metode R\&D modifikasi model Borg \& Gall sampai pada tahap validasi ahli \& uji coba terbatas terhadap pengguna. Sebanyak 24 guru PAUD Aisyiyah terlibat dalam uji coba terbatas. Data dikumpulkan menggunakan kuesioner respon pengguna dan dianalisis secara deskriptif. Hasil penelitian ini adalah prototype produk e-Report PAUD Aisyiyah Versi 1.0 berbasis Ms. Excel memiliki kelayakan segi materi 0,833-1,000 dan 0,5 1,000 dari segi teknologi komputer berdasarkan penilaian validasi ahli, sedangkan hasil ujicoba terbatas menunjukkan bahwa produk ini diterima dengan baik, mudah, pratis, dan efisien. Namun, beberapa perbaikan teknis masih terus dilakukan untuk menyempurnakannya.
\end{abstract}

Kata Kunci: prototype, e-report versi 1.0; laporan perkembangan; anak usia dini.

\begin{abstract}
Along with the development of technology, child development reports are compiled using computerapplications. However, the readiness of PAUD teachers in terms of computer literacy is limited to the use of Ms. Office (Ms. Word, Ms. Excel, and Ms. Power Point) simply. Therefore, this research was conducted to design a prototype of a child development report using Ms.Excel to support the work of PAUD teachers. The research was conducted with the R\&D method of modifying the Borg \&Gall model up to the stage of expert validation \&trials are limited to the user. A total of 24 Aisyiyah PAUD teachers were involved in the limited trial. The data was collected using user response questionnaires and analyzed descriptively. The results of this study are prototypes of the Aisyiyah Aisyiyah Version 1.0 e-Report product based on Ms. Excel has material feasibility of 0.833-1,000 and 0.5 - 1,000 in terms of computer technology based on expert validation assessments, while limited trial results show that this product is well received, easy, pret, and efficient. However, some technical improvements are still being made to perfect it.
\end{abstract}

Keywords: prototype; e-report 1.0 version; development report; early childhood

Copyright (c) 2022 Prima Suci Rohmadheny, et al.

$\triangle$ Corresponding author:

Email Address : prima.rohmadheny@pgpaud.uad.ac.id (Yogyakarta, Indonesia)

Received 12 July 2021, Accepted 23 January 2022, Published 26 January 2022 


\section{PENDAHULUAN}

Dalam melaksanakan pekerjaannya, pendidik PAUD memiliki tugas utama mulai dari merencanakan pembelajaran, melaksanakan kegiatan pembelajaran, sampai dengan melakukan penilaian, evaluasi, dan melaporkan perkembangan anak kepada orangtua (Indonesia, 2014a). Pembelajaran pada anak usia dini meliputi kegiatan main terprogram dan pembiasaan yang dilakukan untuk menstimulasi seluruh aspek perkembangan anak, baik itu nilai agama moral, fisik motorik, kognitif, bahasa, dan sosial emosional. Program pembelajaran dikatakan berhasil, jika anak didik mengalami perkembangan selama dan setelah pembelajaran dilakukan. Agar perkembangan anak dapat diketahui oleh orangtua dan pendidik, maka perlu adanya komunikasi. Salah satu upaya dalam mengomunikasikan perkembangan anak antara pendidik dan orangtua adalah melalui laporan perkembangan anak.

Laporan perkembangan anak usia dini, bukan terdiri dari data kuantatif semata melainkan kualitatif. Pendidik menarasikan perkembangan anak yang telah tercapai, yang belum tercapai, dan merekomendasikan stimulasi yang perlu dilanjutkan melalui laporan perkembangan tersebut (Suminah et al., 2015). Selama ini guru PAUD lebih banyak melakukan penyusunan laporan secara naratif tersebut melalui tulisan tangan. Kemudian dengan berkembangnya teknologi komputer saat ini, lalu kompetensi pendidik PAUD yang diharapkan mampu memanfaatkan teknologi informasi dalam melaksanakan tugas dan pekerjaannya (Sugiarti, 2013), disertai dengan digunakannya kurikulum 2013 PAUD, maka laporan perkembangan anak perlu disusun menggunakan teknologi komputer. Laporan perkembangan anak pun harus disertai foto aktivitas yang mewakili capaian perkembangan anak sebagai bukti otentik.

Berdasarkan hasil penelitian sebelumnya, disebutkan aplikasi Ms. Office merupakan aplikasi yang paling banyak dikuasai oleh pendidik PAUD sebagai bentuk kesiapan guru PAUD dalam literasi komputer (Pramudyani et al., 2019a). Hal tersebut berbeda dengan kondisi yang terjadi di berbagai negara lain dalam hal kesiapan guru dalam menggunakan teknologi komputer, seperti termasuk studi kasus di Malaysia dan Afrika Selatan (Du Plessis \& Webb, 2012; Kumar et al., 2008). Oleh sebab itu, kondisi yang menjadi baseline dalam penelitian ini adalah kondisi yang relevan dan dibutuhkan oleh pendidik PAUD di Indonesia.

Belum semua pendidik PAUD di Indonesia memiliki keterampilan yang baik dalam mengoperasikan Ms. Office. Beberapa tools dasar dalam aplikasi tersebut sudah dikuasai dan digunakan untuk menunjang tugas administrasi pembelajaran guru PAUD. Di samping itu, melalui hasil observasi studi pendahuluan kepada pendidik PAUD Aisyiyah di salah satu wilayah Indonesia ditemukan beberapa persoalan lain yang dihadapi oleh guru PAUD dalam membuat laporan perkembangan anak seperti: kesulitan dan membutuhkan waktu lebih lama ketika melakukan setting layout tampilan laporan perkembangan, kesulitan mengatur ukuran foto setelah insert foto dan melakukan pengetikkan teks, kesulitan mengatur ukuran kertas untuk menyesuaikan dengan kertas LPPAD yang digunakan ketika akan mencetak, mengatur tabel dan pengaturan posisinya. Bagi sebagian besar pendidik PAUD, persoalan-persolan tersebut dirasakan kurang efektif sehingga guru PAUD membutuhkan aplikasi khusus yang lebih praktis dan memudahkan pekerjaannya dalam menyusun laporan perkembangan anak (Rohmadheny \& Pramudyani, 2019). Pendidik PAUD Aisyiyah menghadapi persoalanpersoalan tersebut karena menggunakan aplikasi Ms. Word dalam menyusun laporan perkembangan anak dan mencetaknya sesuai ukuran kertas yang telah ditetapkan di Aisyiyah Pusat. Oleh sebab itu, melalui penelitian ini dikembangkan aplikasi berbasis komputer (memanfaatkan Ms. Offic Excel) untuk menyusun laporan perkembangan anak secara praktis dengan tetap memperhatikan prinsip pelaporan perkembangan anak pada kurikulum yang berlaku sesuai dengan kesiapan guru PAUD terhadap literasi komputer. 


\section{METODOLOGI}

Penelitian ini mengadaptasi model R\&D dari Borg\&Gall sampai dengan tahap kelima dari total sepuluh tahapan (Gall et al., 1996). Prosedur tersebut diawali dengan tahap pertama yaitu studi pendahuluan, tahap kedua perencanaan, tahap ketiga pengembangan produk awal, tahap keempat validasi desain dan tahap uji coba kelompok kecil (terbatas). Pada tahap studi pendahuluan, peneliti melakukan analisis kebutuhan untuk mendapatkan data yang diperlukan dalam mengembangkan produk yang sesuai dengan kebutuhan di lapangan. Pada tahap ini, analisis dilakukan terhadap model laporan perkembangan anak yang digunakan di lingkup PAUD Aisyiyah saat ini yaitu dalam hal formatnya serta penyesuaian dengan kurikulum 2013 PAUD.

Pada tahap kedua yaitu tahap perencanaan, peneliti melakukan 2 hal pada tahap ini. Pertama, peneliti menentukan jenis produk yang akan dikembangkan dan kedua peneliti menentukan spesifikasi produknya. Berikutnya pada tahap ketiga, yaitu tahap pengembangan produk awal peneliti mengembangkan prototipe e-Report 1.0 Aisyiyah berdasarkan spesifikasi dan fitur yang telah ditentukan sebelumnya. Terakhir, tahap keempat dilakukan uji coba terbatas terhadap prototype e-Report PAUD Aisyiyah yang telah dikembangkan untuk menguji keberterimaan produk oleh pengguna, yaitu guru PAUD. Prosedur tersebut dapat lebih dicermati melalui bagan alir pada gambar 1 .

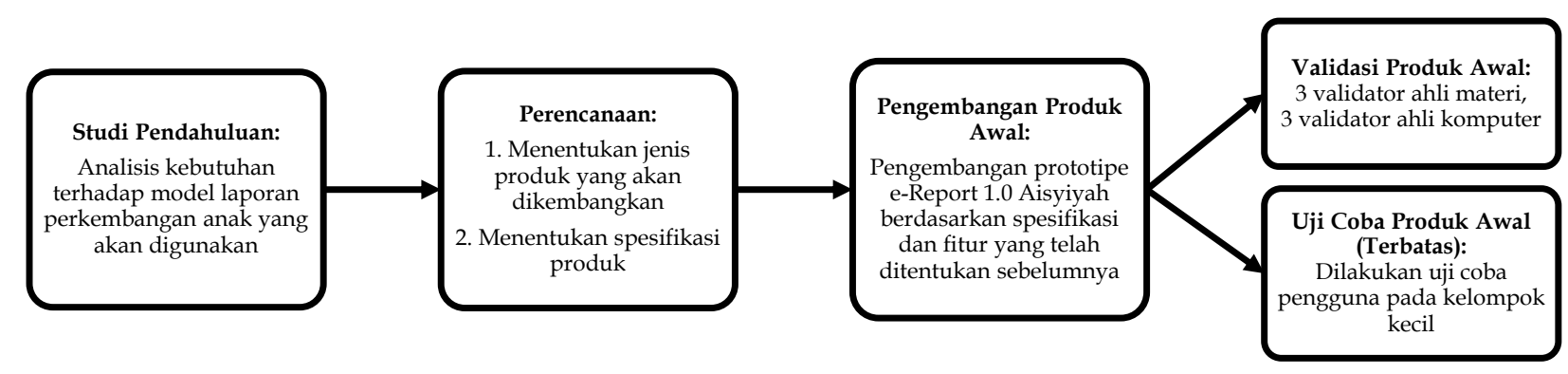

Gambar 1. Prosedur Penelitian dan Pengembangan e-Report 1.0 Aisyiyah

Penelitian ini dilakukan bermitra dengan salah satu PAUD unggulan di lingkup PAUD Aisyiyah yaitu PAUD Nuraini Yogyakarta, sehingga penelitian ini melibatkan guru yang bertugas sebagai tim pengembang kurikulum di lembaga tersebut dan pimpinan lembaga sebagai informan dalam proses analisis kebutuhan, serta guru wali sebagai peserta uji coba produk awal dalam lingkup terbatas. Studi pendahuluan dilakukan dengan diskusi dan pencermatan dokumen laporan perkembangan anak yang diperoleh dari PAUD Nuraini Yogyakarta di mana lembaga ini telah menjadi percontohan dan pusat magang guru PAUD terutama PAUD Aisyiyah dari berbagai wilayah di Indonesia. Setelah prototype produk awal siap, dilakukan uji coba awal dengan melakukan validasi ahli sebanyak 6 ahli. Hasil validasi ahli dilakukan analisis inter rater menggunakan rumus aikens-V. Untuk uji keberterimaan melibatkan 24 guru PAUD Aisyiyah dan mereka mengisi kuesioner respon pengguna. Kuesioner terdiri dari 5 pertanyaan sederhana dengan skala likert dan sebuah pertanyaan terbuka.

\section{HASIL DAN PEMBAHASAN}

Setelah proses penelitian dan pengembangan dilakukan sampai dengan tahap keempat, maka berikut disajikan hasil dan pembahasan sesuai tahap pengembangan yang telah dilakukan.

\section{Studi Pendahuluan}

Studi pendahuluan dilaksanakan dengan diskusi dan pencermatan dokumen laporan perkembangan anak format PAUD Aisyiyah. Diskusi dilakukan bersama pimpinan PAUD 
Aisyiyah Nuraini Yogyakarta dan ketua tim pengembang kurikulum lembaga tersebut. Melalui diskusi dan didukung dengan hasil pencermatan dokumen laporan perkembangan anak format PAUD Aisyiyah diperoleh hasil sebagai berikut: (a) PAUD Aisyiyah menggunakan acuan kurikulum 2013 PAUD sehingga laporan perkembangan anak memuat ruang untuk menuliskan narasi laporan 6 aspek perkembangan anak yaitu nilai agama dan moral, fisik motorik, kognitif, bahasa, sosial emosional, dan seni; (b) PAUD Aisyiyah memiliki muatan materi AIK (Al Islam dan Kemuhammadiyahan) dan terdapat indikator capaian tiap usia untuk disertakan dalam laporan perkembangan anak. Format tersebut yang digunakan dalam pengembangan desain prototype e-Report PAUD Aisyiyah 1.0 yang membedakan dengan aplikasi sejenis yang pernah dikembangkan sebelumnya yaitu aplikasi Palapa yang hanya menyediakan menu sederhana pelaporan perkembangan anak secara umum untuk 6 aspek perkembangan anak saja (Wijayanti, 2018).

Lembaga PAUD di bawah naungan Aisyiyah merupakan lembaga yang mengembangkan kurikulumnya menggunakan acuan nasional dan muatan lokal. Acuan nasional yang digunakan didasarkan pada Peraturan Menteri Pendidikan Nomor 137 tahun 2014 tentang standar nasional PAUD dan Peraturan Menteri Pendidikan Nomor 146 tahun 2014 tentang Kurikulum 2013 PAUD. Penerapan acuan tersebut menjadikan PAUD Aisyiyah merancang, melaksanakan, serta mengevaluasi perkembangan anak terhadap 6 aspek pokok yaitu nilai agama dan moral, fisik motorik, kognitif, bahasa, sosial emosional, dan seni (Indonesia, 2014a, 2014b; Suryana, 2016). Berdasarkan kurikulum 2013 PAUD tersebut, maka penilaian perkembangan anak menerapkan pendekatan penilaian otentik (Yus, 2015; Zahro, 2015). Penilaian otentik menjadi suatu alternatif penilaian berdasarkan kurikulum yang menekankan pada kondisi nyata atau fakta empiris tentang perkembangan anak (Bagnato, 2005, 2007; Grisham-Brown et al., 2006; Macy \& Bagnato, 2013; Puckett \& Black, 2000). Lalu, mendokumentasikan hasil asesmen perkembangan anak merupakan hal yang perlu dilakukan agar guru dan orang tua dapat menggunakan sebagai bahan evaluasi dan perbaikan program kegiatan untuk anak (Reynolds, 2020)

Muatan tersebut berbeda dengan muatan lokal yang digunakan. Acuan muatan lokal yang menjadi ciri khas bagi lembaga PAUD Aisyiyah menggunakan muatan Al Islam dan Kemuhamadiyahan (AIK) yang telah dikembangkan oleh tim melalui organisasi Aisyiyah. Muatan tersebut berisi pengenalan terhadap ORTOM (organisasi otonom muhammadiyah) melalui logo, nama, dan penjelasan tiap jenis organisasinya, surat-surat pendek, bacaan dan gerakan sholat, wudhu, hadist dan doa-doa harian, dan sebagainya. Muatan pembelajaran Al Islam dan Kemuhammadiayahan tersebut diberikan sejak usia dini karena dapat menjadi basis pengembangan karakter (Baidarus et al., 2020). Meskipun pembelajaran wudhu tidak hanya dikenalkan pada peserta didik Islam di PAUD Aisyiyah saja melainkan juga di PAUD Islam lainnya (Revita \& Hartati, 2020), namun muatan materi ini merupakan bagian tak terpisahkan dari muatan lokal AIK. Karena bagi lembaga pendidikan pada parsyarikatan muhammadiyah, muatan pembelajaran tersebut memiliki tujuan antara lain sebagai sarana pendidikan dan pencerdasan, pelayanan masyarakat, dan kaderisasi (Nuryana, 2019).

Pada awalnya, muatan ini terpisah dari muatan pembelajaran yang dirumuskan berdasarkan acuan nasional kurikulum 2013 PAUD. Namun pada perkembangan terbaru, muatan lokal tersebut mulai diintegrasikan dalam muatan pembelajaran berdasarkan acuan nasional sehingga pengembangan fitur perlu diperbarui terus menerus sesuai kebijakan terbaru yang digunakan. Perkembangan ini menjadi salah satu hal yang menjadi dasar dalam upaya untuk terus melakukan upgrading desain produk e-report agar sesuai dengan kebutuhan pengguna.

\section{Perencanaan}

Penelitian dan pengembangan ini menggunakan hasil studi pendahuluan sebagai dasar dalam membuat perencanaan. Pada tahap perencanaan telah dihasilkan 2 pokok rencana, antara lain: (a) penentuan jenis produk yang dikembangkan yaitu berupa laporan 
perkembangan anak berbasis komputer dengan menggunakan aplikasi Ms. Excel dan (b) penentuan fitur dan spesifikasi yang diperlukan berdasarkan hasil studi pendahuluan. Fitur dan spesifikasi produk ditentukan sebagai berikut; a) Beranda (home); Bagian ini merupakan bagian awal yang akan tampil kali pertama setelah membuka aplikasi, b) Identitas anak; Pada bagian ini guru melakukan input data nama anak, nomor induk anak, foto anak, tempat tanggal lahir (otomatis usia muncul), nama orangtua, alamat, nomor telepon orangtua, pasfoto anak, c) Halaman input laporan perkembangan anak; Bagian merupakan sheet untuk input deskripsi laporan perkembangan anak pada 6 lingkup perkembangan dan laporan hasil evaluasi capaian muatan AIK. Pada sheet ini guru dapat melihat hasil evaluasi capaian perkembangan anak pada setiap lingkup perkembangan dalam bentuk narasi dan rekomendasi bagi orangtua, d) Halaman cetak laporan perkembangan anak; Bagian ini merupakan sheet hasil isian yang siap cetak, memudakan guru tanpa harus mengatur letak foto dan perubahan halaman. Cetak terbagi menjadi 3, yaitu cetak 1 merupakan pencetakan identitas anak dan bagian awal laporan perkembangan anak kemudian cetak 2 berisi narasi laporan 6 aspek perkembangan, dan cetak 3 berisi hasil evaluasi capaian muatan AIK.

\section{Pengembangan Produk Awal}

Berdasarkan perencanaan yang telah dirancang pada tahap kedua di atas, maka pada tahap ketiga ini dilakukan pengembangan produk awal. Desain prototype dari pengembangan produk awal e-Report 1.0 PAUD Aisyiyah dapat dicermati pada tabel 1 (lampiran).

Berdasarkan desain pada tabel 1, dapat ditemukan bahwa prototype e-Report PAUD Aisyiyah 1.0 ini bukan saja dapat digunakan untuk membantu guru dalam menyusun laporan perkembangan anak, melainkan dapat sekaligus digunakan sebagai sarana dalam melakukan input data induk anak secara terintregasi. Hal yang paling penting juga dalam pengembangan ini adalah memberikan bantuan bagi guru dengan tetap memberi ruang bagi guru untuk belajar dan menerapkan prinsip-prinsip dalam penilaian dan pelaporan perkembangan anak. Guru tetap harus memiliki keterampilan dalam menyusun narasi laporan perkembangan anak dan aplikasi berbasis excel ini sebagai alat bantunya. Karena, pada faktanya masih ada banyak guru belum memiliki kemampuan yang memadai untuk melakukan asesmen dan pelaporan perkembangan anak sesuai prinsip-prinsip yang seharusnya (Sari \& Setiawan, 2020). Dengan demikian guru tidak hanya bergantung dan laporan perkembangan anak tetap memuat kalimat yang luwes sesuai keunikan serta perkembangan setiap individu anak sesuai usianya.

Prototype ini setelah dipastikan kelayakan dan efektivitasnya melalui tahap pengembangan berikutnya, akan membantu guru PAUD Aisyiyah dalam menyusun laporan perkembangan anak. Guru bukan saja terbantu ketika menyusun laporan perkembangan anak pada masa normal atau normal, namun juga selama pandemic covid 19 masih berlangsung dengan mengakomodasi data perkembangan anak yang disampaikan oleh orangtua (Maryani, 2020).

\section{Hasil Ujicoba Produk Awal}

Uji coba produk awal dilakukan dengan validasi produk e-Report 1.0 PAUD Aisyiyah dan uji coba kelompok kecil. Data diperoleh berupa prosentase kelayakan produk dan respon dari 24 pengguna yang berupa data ordinal dan data kualitatif. Data ordinal diperoleh dari skala yang diberikan oleh validator dan respon pengguna selama praktik menyusun laporan perkembangan anak menggunakan e-Report 1.0 PAUD Aisyiyah, sedangkan data kualitatif merupakan catatan rekomendasi perbaikan dari validator dan masukan pengguna terhadap e-Report 1.0 PAUD Aisyiyah. Berikut data yang dihasilkan.

\section{Hasil validasi e-Report 1.0 PAUD Aisyiyah}

E-report yang dikembangkan peneliti telah melalui uji validitas yang terdiri dari uji validitas materi dan uji validitas program. Uji validitas dilakukan oleh tiga orang ahli materi 
dan tiga orang ahli komputer, masing-masing memberikan penilaian pada instrumen yang tersedia dengan rentang skor 1-5. Skor 1 berarti aitem dinilai sangat tidak sesuai sedangkan skor 5 berarti aitem dinilai sangat sesuai. Selanjutnya hasil penilaian para ahli dianalisis dengan formula Aiken's V dengan rumus pada gambar 2. Sebuah aitem dianggap valid jika memiliki $\mathrm{V}$ sebesar 0.5 atau lebih.

$$
\mathrm{V}=\sum \mathrm{s} /[\mathrm{n}(\mathrm{c}-1)]
$$

Gambar 2. Rumus Aiken's V

Keterangan:

$\mathrm{S}=\mathrm{r}-\mathrm{lo}$

Lo = Angka penilaian validitas terendah (yaitu 1)

$\mathrm{C}=$ Angka penilaian validitas tertinggi (yaitu 5)

$\mathrm{R}=$ Angka yang diberikan oleh seorang expert

\section{Hasil penilaian Ahli Materi}

Tabel 1 merupakan data yang diperoleh melalui penilaian validasi ahli yang terdiri dari 3 ahli materi kurikulum PAUD dan 3 ahli komputer.

Tabel 1. Hasil penilaian ahli materi

\begin{tabular}{ccccr}
\hline $\begin{array}{c}\text { Nomor } \\
\text { Aitem }\end{array}$ & Expert 1 & RATING (1-5) & & \\
Expert 2 & Expert 3 & Aiken's V \\
\hline $\mathbf{1}$ & 5 & 5 & 5 & 1,000 \\
$\mathbf{2}$ & 4 & 5 & 5 & 0,917 \\
$\mathbf{3}$ & 5 & 5 & 5 & 1,000 \\
$\mathbf{4}$ & 4 & 5 & 5 & 0,917 \\
$\mathbf{5}$ & 4 & 5 & 5 & 0,917 \\
$\mathbf{6}$ & 4 & 5 & 5 & 0,917 \\
$\mathbf{7}$ & 5 & 4 & 5 & 0,917 \\
$\mathbf{8}$ & 4 & 5 & 5 & 0,917 \\
$\mathbf{9}$ & 4 & 5 & 5 & 0,917 \\
$\mathbf{1 0}$ & 5 & 4 & 5 & 0,917 \\
$\mathbf{1 1}$ & 4 & 4 & 5 & 0,833 \\
\hline
\end{tabular}

Hasil hitung Aiken's V dari penilaian ahli materi di tabel 1 menunjukkan skor yang berada pada rentang 0,833 hingga 1,000. Hal ini menunjukkan bahwa materi pada program ereport dinilai valid oleh para ahli. Skor maksimal diberikan pada aitem no 1 dan no 3, yang mengungkapkan bahwa kelengkapan lingkup perkembangan sesuai dengan lingkup perkembangan pada kurikulum 2013 PAUD dan menu pelaporan capaian perkembangan anak terhadap muatan kearifan lokal TK aisyiyah sudah sangat sesuai dengan yang seharusnya. Artinya, kebutuhan pengguna yang telah dianalisis sebelumnya telah terakomodasi dalam sistem aplikasi yang dikembangkan ini.

Skor terendah dalam penilaian ini diberikan pada aitem nomor 11 yaitu aplikasi dinilai telah memfasilitasi integrasi data induk peserta didik dengan data perkembangan anak dalam satu kesatuan. Pada aitem ini, dua orang rater memberikan penilaian 'sesuai' dan satu orang rater memberikan penilaian 'sangat sesuai'. Meskipun aitem ini mendapat penilaian paling rendah $(0,833)$, namun secara norma intepretasi formula Aiken's V skor tersebut berada di atas 0,5 sehingga dikatakan valid. Selama ini data induk di berbagai jenjang pendidikan terpisah dengan data lainnya, bahkan meskipun telah dikembangkan sistem informasi penyimpanan data induk peserta didik seperti yang dilakukan Ratnawati \& Riasti (2012) namun data tersebut belum terintegrasi. 
Integrasi data pada masa saat ini menjadi sesuatu hal yang penting dan dibutuhkan untuk memudahkan penyimpanan dan mengorganisasikan data. Seperti halnya integrasi data pada beberapa jenis integrasi data dalam beberapa hasil penelitian antara lain: sistem integrasi data desa, integrasi data pada pangkalan akademik perguruan tinggi, integrasi data rekam medis di bidang kesehatan, bahkan digunakannya suatu karakter control untuk mengintegrasikan data hasil enkripsi algoritma (Amin, 2014; Hammad, 2019; Perwira \& Santosa, 2017; R et al., 2019; Winarno \& Cahyanto, 2021). Oleh sebab itu, aplikasi ini meskipun sederhana namun telah berkontribusi untuk memfasilitasi pendidik PAUD dalam mengorganisasikan data peserta didik secara terintegrasi.

\section{Hasil Penilaian Ahli Komputer}

Ahli computer yang melakukan validasi terhadap e-Report PAUD Aisyiyah 1.0 ini sebanyak 3 orang. Berikut ini merupakan tabel data hasil penilaian ahli komputer terhadap prototype e-Report PAUD Aisyiyah 1.0 dapat dilihat pada tabel 2.

Tabel 2. Hasil penilaian ahli komputer

\begin{tabular}{ccccr}
\hline $\begin{array}{c}\text { Nomor } \\
\text { Aitem }\end{array}$ & \multicolumn{5}{c}{ RATING (1-5) } & \\
\hline $\mathbf{1}$ & 5 & 5 & 5 & Expert \\
$\mathbf{2}$ & 5 & 4 & 5 & 0,000 \\
$\mathbf{3}$ & 4 & 5 & 5 & 0,917 \\
$\mathbf{4}$ & 4 & 5 & 5 & 0,917 \\
$\mathbf{5}$ & 4 & 4 & 5 & 0,833 \\
$\mathbf{6}$ & 3 & 3 & 4 & 0,583 \\
$\mathbf{7}$ & 4 & 4 & 4 & 0,750 \\
$\mathbf{8}$ & 3 & 4 & 5 & 0,750 \\
$\mathbf{9}$ & 4 & 3 & 5 & 0,750 \\
$\mathbf{1 0}$ & 3 & 3 & 5 & 0,667 \\
$\mathbf{1 1}$ & 3 & 4 & 5 & 0,750 \\
$\mathbf{1 2}$ & 4 & 4 & 5 & 0,833 \\
$\mathbf{1 3}$ & 4 & 4 & 5 & 0,833 \\
$\mathbf{1 4}$ & 4 & 4 & 5 & 0,833 \\
$\mathbf{1 5}$ & 4 & 4 & 5 & 0,833 \\
$\mathbf{1 6}$ & 4 & 5 & 5 & 0,917 \\
$\mathbf{1 7}$ & 3 & 3 & 5 & 0,667 \\
$\mathbf{1 8}$ & 5 & 3 & 5 & 0,833 \\
$\mathbf{1 9}$ & 5 & 5 & 4 & 0,917 \\
$\mathbf{2 0}$ & 4 & 5 & 5 & 0,917 \\
$\mathbf{2 1}$ & 5 & 5 & 4 & 0,917 \\
$\mathbf{2 2}$ & 4 & 4 & 3 & 0,667 \\
$\mathbf{2 3}$ & 4 & 4 & 1 & 0,500 \\
\hline
\end{tabular}

Hasil hitung Aiken's V dari penilaian ahli komputer di tabel 2 menunjukkan skor yang berada pada rentang 0,5 hingga 1,000. Hal ini menunjukkan bahwa program e-report dinilai valid oleh para ahli dilihat dari 22 aitem, sedangkan terdapat 1 aitem yang dinilai tidak valid. Skor maksimal diberikan pada aitem no 1 yaitu mengenai kejelasan judul aplikasi. Dengan demikian, judul yang diberikan pada program ini dinilai sudah sangat sesuai sehingga tidak perlu dilakukan perubahan.

Validator memberikan catatan bahwa beberapa tombol tidak bekerja saat diakses melalui excel 2021, numbers (macos 12.1) dan excel 2010 (windows 10). Jika semua tombol dan fungsi berjalan berjalan dengan baik di perangkat author (peneliti), mungkin penyebabnya adalah kompabilitas sehingga perlu dicek lebih lanjut mengenai excel versi berapa yang dibutuhkan untuk menjalankan program secara baik. Selain itu rater 3 memberikan saran 
untuk menambahkan requirement versi excel yang kompatibel di dalam petunjuk atau tutorial penggunaan aplikasi. Berdasarkan penilaian ahli komputer di atas maka dapat dikatakan bahwa program ini valid dengan pengecualian aitem nomor 23 dikarenakan beberapa tombol tidak bekerja. Hal ini menjadi evaluasi yang sangat penting bagi peneliti untuk memeriksa kembali program yang sedang dikembangkan.

\section{Hasil uji coba pengguna}

Setelah uji coba dilakukan pada 24 pendidik PAUD Aisyiyah sebagai pengguna, peserta uji coba memberikan respon melalui kuesioner yang telah diberikan dengan beberapa poin pertanyaan. Topik pertanyaan tersebut meliputi kebermanfaatan aplikasi, kemudahan operasional aplikasi, tampilan aplikasi, kelengkapan isi komponen didasarkan pada pengisian laporan perkembangan anak yang selama ini digunakan, tulisan atau font yang digunakan pada aplikasi, dan catatan kualitatif. Berkaitan dengan kebermanfaatan, 91,3\% dari 24 pengguna menyatakan bahwa e-Report 1.0 PAUD Aisyiyah ini sangat bermanfaat dan sisanya menyatakan bermanfaat. Hal tersebut menunjukkan bahwa tingkat kebermanfaatan e-Report 1.0 PAUD Aisyiyah sangat tinggi dalam membantu menunjang pekerjaan profesional guru PAUD dalam menyusun laporan perkembangan anak. Kebermanfaatan yang dirasakan oleh pengguna menunjukkan bahwa produk ini dapat diterima oleh mereka.

Selain memiliki kebermanfaatan dalam menunjang pekerjaan mereka, pengguna memberi respon terhadap kemudahan operasional aplikasi ini. Pengguna menyatakan bahwa aplikasi ini sangat mudah digunakan $(82,6 \%)$ dan sebanyak $17.4 \%$ pengguna menyatakan mudah. Hal ini berarti, selain pengguna merasakan manfaat dalam penggunaan aplikasi ini dalam menunjang pekerjaan mereka juga mudahnya dalam menggunakan sehingga pengguna banyak yang mengharapkan aplikasi segera dapat diluncurkan. Seperti pernyataan kualitatif yang dituliskan oleh salah satu pengguna, "Aplikasi ini kami harapkan bisa segera dilauncing".

Aplikasi ini dikembangkan untuk menjawab berbagai keluhan dan kesulitan yang selama ini mereka alami dalam melakukan penilaian dan menyusun laporan perkembangan anak, seperti yang dihasilkan dalam penelitian sebelumnya dengan menggunakan microsoft word. Pada dasarnya memang kesiapan mereka dalam penggunaan komputer masih sangat terbatas pada operasi sederhana yang ada di aplikasi microsoft office (Pramudyani et al., 2019b). Dalam berbagai keperluan, kebermanfaatan dan kemudahan penggunaan suatu aplikasi digital menjadi perhatian yang penting bukan hanya dalam hal layanan pendidikan tetapi juga dalam hal perdagangan (Latipaturachmaniah \& Rahayu, 2021; Nofita, 2021; Pillai et al., 2021; Robaniyah \& Kurnianingsih, 2021; Salsabila et al., 2021; Saripudin \& Faihaputri, 2021; Sibuea et al., 2021). Latipaturachmaniah \& Rahayu (2021) lebih mengarah pada penggunaan aplikasi media sosial line bagi para penggunanya.

Di lingkungan pendidikan, Pillai et al. (2021) menyebutkan tentang hasil penelitiannya yang menganalisis kemudahan dari penggunaan Augmented Reality (AR) untuk menunjang pembelajaran daring. Penelitian selain itu menganalisis kemudahan dan kemanfaatan aplikasi belanja online yang digunakan oleh para pengguna serta pengaruhnya terhadap minat beli. Fakta-fakta tersebut menunjukkan bahwa pentingnya penerimaan pengguna ditinjau dari perspektif kebermanfaatan dan kemudahan penggunaanya terhadap aplikasi e-Report PAUD Aisyiyah 1.0 ini. Di samping itu, aplikasi ini memang telah dikembangkan berdasarkan tingkat kesiapan mereka dalam mengoperasikannya, selain dirasakan lebih praktis digunakan.

Selain dua hal tersebut, pengguna (responden) menyatakan tentang kemenarikan tampilan e-Report PAUD Aisyiyah 1.0. Data yang dihasilkan disajikan pada diagram 1 berikut. 


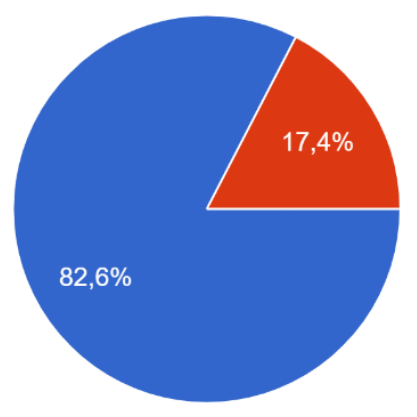

Menarik

Cukup Menarik

Kurang Menarik

Tidak Menarik

Diagram 1. Tampilan Aplikasi e-Report PAUD 1.0

Berdasarkan diagram 3, tampak bahwa sebesar $82,6 \%$ pengguna menyatakan tampilan aplikasi e-Report 1.0 PAUD Aisyiyah ini menarik dan sisanya sebesar $17.4 \%$ pengguna menyatakan bahwa aplikasi ini cukup menarik. Sebesar 82,6 \% responden tersebut memiliki kecenderungan trend yang sama dalam menyatakan kebermanfaatan dan kemenarikan tampilan aplikasi e-Report ini, yaitu maksimal. Hasil ini relevan dan mendukung data hasil penilaian ahli komputer yang mendapatkan hasil valid pada aitem kemenarikan tampilan aplikasi.

Selanjutnya berkaitan dengan kelengkapan isi komponen pada aplikasi e-Report PAUD Aisyiyah ini. Sebanyak 52, 2\% pengguna menyatakan lengkap, kemudian 39,1\% menyatakan cukup lengkap dan sisanya menyebutkan kurang lengkap. Hal ini menjadi hal menarik untuk kemudian diharapkan masukan responden melalui catatan kualitatif yang disediakan.
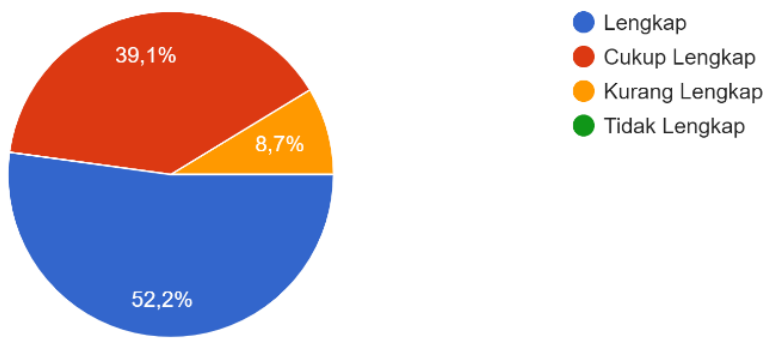

Diagram 1. Kelengkapan komponen e-Report PAUD Aisyiyah 1.0

Melalui diagram 1 di atas dapat kita cermati bahwa masih ada celah dari produk yang dikembangkan ini untuk lebih dapat dilengkapi komponennya.

Di samping itu, tulisan atau font yang digunakan pada aplikasi ini juga perlu menjadi perhatian. Responden menyatakan tulisan yang digunakan pada aplikasi ini sudah jelas $(91,3 \%)$, sedangkan hanya $8,7 \%$ responden yang menyebutkan cukup jelas. Data yang dapat dicermati pada diagram 2 ini sudah cukup untuk disimpulkan bahwa tulisan pada aplikasi ini mendapat penerimaan baik oleh pengguna.

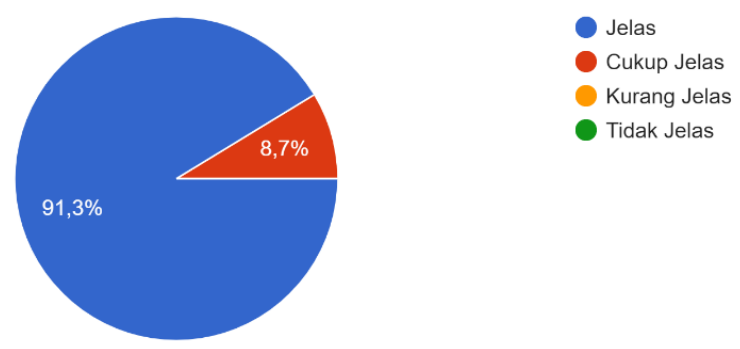

Diagram 2. Kejelasan Tulisan Pada Aplikasi E-Report PAUDAisyiyah 1.0 
Selain itu, pengguna memberikan respon secara kualitatif antara lain: mudah, praktis, lebih efektif dan efisien, tepat sasaran, menambah keterampilan dan kemampuan baru. Hal tersebut dapat dimaknai bahwa prototipe e-Report PAUD Aisyiyah 1.0 ini sesuai dengan tujuan awal pengembangan dalam memberikan kemudahan pekerjaan pendidik PAUD dalam menyusun laporan perkembangan. Dengan demikian, e-Report PAUD Aisyiyah ini layak untuk dilanjutkan proses pengembangannya hingga dapat digunakan oleh pendidik PAUD Aisyiyah. Respon ini tentu dapat mendukung dalam penggunaannya selama masa pandemi covid 19, karena lebih praktis dan meskipun pembelajaran dilakukan dengan BDR namun laporan perkembangan anak tetap harus disampaikan pada orangtua (Maryani, 2020). Aplikasi ini tentu berbeda dengan aplikasi yang telah dikembangkan dengan sistem informasi yang telah dilakukan oleh (Ratnawati \& Riasti, 2012)

Pengguna juga memberikan catatan perbaikan antara lain penambahan jumlah ruang untuk insert foto dokumentasi kegiatan anak yang mewakili perkembangannya pada setiap aspek, nama lembaga yang diinput belum berubah di kop laporan perkembangan meskipun sudah merubah biodata lembaga, penyesuaian skala capaian perkembangan yang digunakan dari yang awal menurut pedoman penilaian yang disusun oleh Suminah et al. (2015) berupa BB (Belum Berkembang), MB (Mulai Berkembang, BSH (Berkembang Sesuai Harapan), dan BSB (Berkembang Sangat Baik) menjadi disesuaikan menjadi AP (Awal Perkembangan), B (Berkembang), dan C (Cakap). Skala tersebut merupakan kesepakatan yang ditetapkan oleh pengurus pusat Aisyiyah untuk digunakan di PAUD dengan pertimbangan bahwa perkembangan apapun pada anak di awal perlu dihargai sehingga disebut awal perkembangan. Kemudian untuk yang telah berkembang berapa pada level B (Berkembang), sedangkan yang telah terampil melebihi standar minimal capaian perkembangannya disebut Cakap (C).

\section{SIMPULAN}

Pengembangan desain prototype e-Report PAUD Aisyiyah 1.0 ini telah disesuaikan dengan kebutuhan pengguna, meskipun membutuhkan pembaruan secara berkala menyesuaikan perkembangan di lapangan. Prototype e-Report PAUD Aisyiyah 1.0 yang bukan hanya dapat digunakan sebagai alat bantu pelaporan perkembangan anak, tetapi juga dapat digunakan sebagai sarana penyimpanan data induk anak didik. Produk e-Rpeort PAUD Aisyiyah 1.0 dinyatakan valid oleh 3 orang ahli materi kurikulum PAUD dan 3 orang ahli komputer, serta dapat diterima oleh pengguna, meskipun masih ada beberapa catatan perbaikan sebagai dasar dalam melakukan revisi produk.

\section{UCAPAN TERIMA KASIH}

Ucapan terimakasih disampaikan pada LPPM Universitas Ahmad Dahlan yang telah memberikan dukungan dalam pelaksanaan penelitian ini.

\section{DAFTAR PUSTAKA}

Amin, M. M. (2014). Implementasi framework interoperabilitas dalam integrasi data rekam medis. Pseudocode, 1(1), 44-50. https://doi.org/10.33369/pseudocode.1.1.44-50

Bagnato, S. J. (2005). The authentic alternative for assessment in early intervention: An emerging evidence-based practice. Journal of Early Intervention, 28(1), 17-22. https://doi.org/10.1177/105381510502800102

Bagnato, S. J. (2007). Authentic assessment for early childhood intervention: Best practices. Guilford Press.

Baidarus, B., Hamami, T., M. Suud, F., \& Rahmatullah, A. S. (2020). Al-Islam dan kemuhammadiyahan sebagai basis pendidikan karakter. AL-ASASIYYA: Journal Of Basic Education, 4(1), 71. https://doi.org/10.24269/ajbe.v4i1.2101 
Du Plessis, A., \& Webb, P. (2012). Teachers' Perceptions about their Own and their Schools' Readiness for Computer Implementation: A South African Case Study. Turkish Online Journal of Educational Technology - TOJET, 11(3), 312-325.

Gall, M. D., Borg, W. R., \& Gall, J. P. (1996). Educational research: An introduction. Longman Publishing.

Grisham-Brown, J., Hallam, R., \& Brookshire, R. (2006). Using authentic assessment to evidence children's progress toward early learning standards. Early Childhood Education Journal, 34(1), 45-51. https:// doi.org/10.1007/s10643-006-0106-y

Hammad, R. (2019). Analisis integrasi data pada realisonal basis data dengan menggunakan metode schema matching. Jurnal SAINTEKOM, 9(1), 1. https:// doi.org/10.33020/saintekom.v9i1.79

Indonesia, R. (2014a). Peraturan Menteri Pendidikan dan Kebudayaan Nomor 137 Tahun 2014 tentang Standar Nasional Pendidikan Anak Usia Dini.

Indonesia, R. (2014b). Peraturan Menteri Pendidikan dan Kebudayaan Republik Indonesia Nomor 146 Tahun 2014 Tentang Kurikulum 2013 Pendidikan Anak Usia Dini. Kementerian Pendidikan dan Kebudayaan Republik Indonesia.

Kumar, N., Rose, R. C., \& D'Silva, J. L. (2008). Teachers' readiness to use technology in the classroom: An empirical study. European Journal of Scientific Research, 21(4), 603-616.

Latipaturachmaniah, L., \& Rahayu, E. F. (2021). Analisis Kemudahan Penggunaan Aplikasi Line Pada Ponsel Pintar. UG Journal, 15(2).

Macy, M., \& Bagnato, S. J. (2013). The authentic alternative for assessment in early childhood intervention. In The Oxford Handbook of Child Psychological Assessment.

Maryani, K. (2020). Penilaian dan Pelaporan Perkembangan Anak Saat Pembelajaran di Rumah di Masa Pendemi Covid-19. Murhum : Jurnal Pendidikan Anak Usia Dini, 4152. https:// doi.org/10.37985/murhum.v1i1.4

Nofita, F. D. (2021). Pengaruh Kepercayaan Pelanggan, Kemudahan Penggunaan Aplikasi, Citra Perusahaan Dan Electronic Word Of Mouth Terhadap Keputusan Pembelian Online (Studi Kasus Lazada Kota Padang) [PhD Thesis]. STKIP PGRI Sumatera Barat.

Nuryana, Z. (2019). Revitalisasi Pendidikan Al-Islam Dan Kemuhammadiyahan Pada Perguruan Muhammadiyah [Preprint]. Open Science Framework. https:// doi.org/10.31219/osf.io/yk3qv

Perwira, R., \& Santosa, B. (2017). Implementasi Web Service pada Integrasi Data Akademik dengan Replika Pangkalan Data Dikti. Telematika, 14(01). https:// doi.org/10.31315/telematika.v14i01.1962

Pillai, S. K., Iksan, N., Abd Arif, H., Panessai, I. Y., Abdulbaqie, A. S., \& Yani, A. (2021). Kemudahan Penggunaan Augmented Reality sebagai Alat Bantu Pembelajaran Online bagi Meningkatkan Kinerja dan Prestasi Siswa Dalam Seni Ukiran Kayu. Journal of Engineering, Technology, and Applied Science, 3(2), 48-57. https:// doi.org/10.36079/lamintang.jetas-0302.256

Pramudyani, A. V. R., Indratno, T. K., \& Rohmadheny, P. S. (2019a). Early Childhood Education Teacher's Readiness of Computer Literacy for Facing The 4.0 Industrial Revolution. Journal of Early Childhood Care and Education, 2(2), 55-63. https:// doi.org/10.26555/jecce.v2i2.1150

Pramudyani, A. V. R., Indratno, T. K., \& Rohmadheny, P. S. (2019b). Early Childhood Education Teacher's Readiness of Computer Literacy for Facing The 4.0 Industrial Revolution. JECCE (Journal of Early Childhood Care and Education), 2(2), 55-63. https:// doi.org/10.26555/jecce.v2i2.1150

Puckett, M. B., \& Black, J. K. (2000). Authentic assessment of the young child: Celebrating development and learning. ERIC.

R, R., Tamin, R., \& Sarjan, M. (2019). Sistem Integrasi Data Musrenbang Desa Berbasis Web. Jurnal Ilmiah Ilmu Komputer, 5(1), 7-12. https://doi.org/10.35329/jiik.v5i1.25 
Ratnawati, R., \& Riasti, B. K. (2012). Pembangunan Sistem Informasi Buku Induk Siswa Pada Sekolah Menengah Kejuruan Wikarya Karanganyar. Speed - Sentra Penelitian Engineering dan Edukasi, 6(3), Article 3. https://doi.org/10.3112/speed.v6i3.1290

Revita, D., \& Hartati, S. (2020). Pelaksanaan pembelajaran ibadah wudhu di taman kanakkanak islam terpadu dar el-iman 2 kota padang. Jurnal Ilmiah Pesona PAUD, 7(1), 26. https://doi.org/10.24036/108650

Reynolds, B. (2020). Assessment and documentation for children's learning and development. In A. Kilderry \& B. Raban (Eds.), Strong Foundations: Evidence informing practice in early childhood education. ACER Press. https://doi.org/10.37517/978-1-74286-5553_17

Robaniyah, L., \& Kurnianingsih, H. (2021). Pengaruh Persepsi Manfaat, Kemudahan Penggunaan Dan Keamanan Terhadap Minat Menggunakan Aplikasi OVO. IMAGE: Jurnal Riset Manajemen, 10(1), 53-62.

Rohmadheny, P. S., \& Pramudyani, A. V. R. (2019). E-LEv: Solution for Early Childhood Education Teachers in Industrial Revolution Era 4.0. 3rd International Conference on Education Innovation (ICEI 2019). https://doi.org/10.2991/icei-19.2019.52

Salsabila, H. Z., Susanto, S., \& Hutami, L. T. H. (2021). Pengaruh Persepsi Risiko, Manfaat Dan Kemudahan Penggunaan Terhadap Keputusan Pembelian Online Pada Aplikasi Shopee. Jurnal Ilmiah Manajemen Kesatuan, 9(1), 87-96. https://doi.org/10.37641/jimkes.v9i1.442

Sari, K. M., \& Setiawan, H. (2020). Kompetensi Pedagogik Guru dalam Melaksanakan Penilaian Pembelajaran Anak Usia Dini. Jurnal Obsesi: Jurnal Pendidikan Anak Usia Dini, 4(2), 900-912. https:// doi.org/10.31004/obsesi.v4i2.478

Saripudin, S., \& Faihaputri, N. (2021). Pengaruh kepercayaan, keamanan, dan kemudahan penggunaan aplikasi terhadap minat beli ulang (studi kasus di e-commerce jd. id). Jurnal Ilmiah Edunomika, 5(02).

Sibuea, S. J., Oktavianthy, D., \& Rangkuti, A. E. (2021). Pengaruh persepsi kemudahan penggunaan dan persepsi manfaat terhadap minat penggunaan aplikasi ovo. Prosiding Konferensi Nasional Social \& Engineering Polmed (KONSEP) 2021, 2(1), 635645.

Sugiarti, Y. (2013). Pendayagunaan Teknologi Informasi Dan Komunikasi Dalam Meningkatkan Kompetensi Guru Pendidikan Anak Usia Dini (PAUD). Jurnal Teknodik, 45-58.https://doi.org/10.32550/teknodik.v0i0.7

Suminah, E., Siantayani, Y., Paramitha, D., Ritayanti, U., \& Nugraha, A. (2015). Pedoman Penilaian Pembelajaran Pendidikan Anak Usia Dini. Direktorat Pembinaan Pendidikan Anak Usia Dini.

Suryana, D. (2016). Pendidikan Anak Usia Dini: Stimulasi \& Aspek Perkembangan Anak. Prenada Media.

Wijayanti, R. (2018). PKM PALAPA (Pembuatan Aplikasi Laporan Perkembangan Anak) Kelompok A Pada TK An Shal Kecamatan Kamal Kabupaten Bangkalan. JAST : Jurnal Aplikasi Sains Dan Teknologi, 2(2), 74. https:// doi.org/10.33366/jast.v2i2.1096

Winarno, N. P. S., \& Cahyanto, T. A. (2021). Penggunaan Karakter Kontrol ASCII Untuk Integrasi Data Pada Hasil Enkripsi Algoritma Caesar Cipher. INFORMAL: Informatics Journal, 6(3), 197. https://doi.org/10.19184/isj.v6i3.21091

Yus, A. (2015). Penilaian Perkembangan Belajar Anak Taman Kanak-kanak. Kencana.

Zahro, I. F. (2015). Penilaian dalam pembelajaran anak usia dini. Tunas Siliwangi: Jurnal Program Studi Pendidikan Guru PAUD STKIP Siliwangi Bandung, 1(1), 92-111. 
Tabel 1. Pengembangan Prototype e-Report 1.0 PAUD Aisyiyah

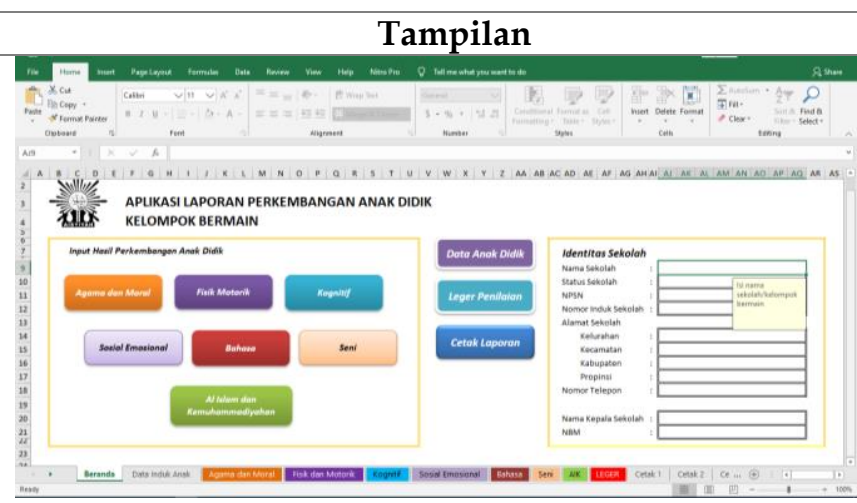

\section{HOME}

Deskripsi

Bagian ini merupakan tampilan beranda awal yang muncul setelah aplikasi dibuka. Pada bagian ini tersedia beberapa menu button antara lain : menu untuk pengisian identitas sekolah, menu isian data anak didik, menu isian narasi laporan perkembangan anak untuk 6 aspek perkembangan sesuai kurikulum 2013 PAUD dan capaian perkembangan muatan AIK (Al Islam Kemuhammadiayahan), menu leger penilaian, dan menu cetak laporan.

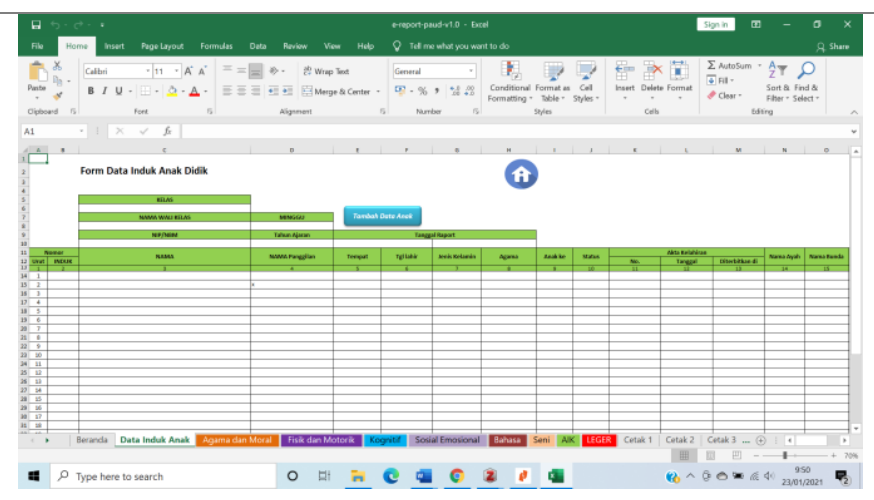

\section{FORM DATA INDUK ANAK}

Pada bagian ini ditampilkan tabel untuk isian data induk anak dalam satu rombongan belajar (rombel). Di sini ada button gambar rumah untuk kembali ke home/beranda dan menu input data anak. Guru dapat melakukan input data anak pada bagian ini.

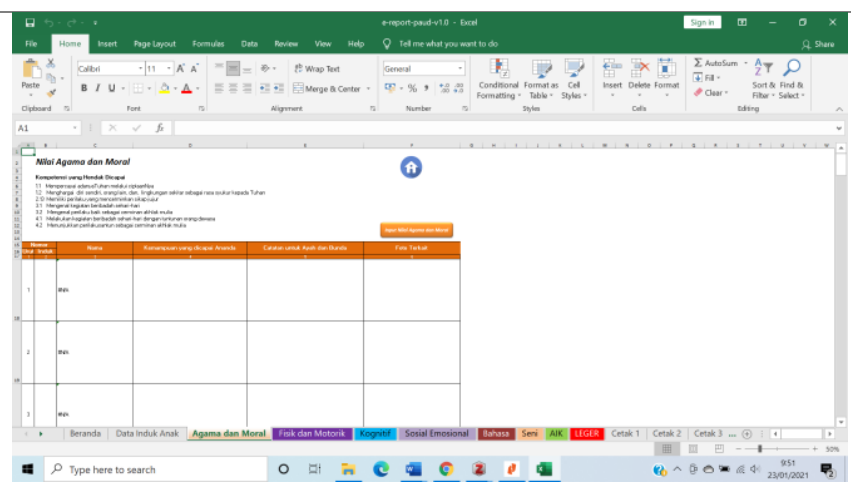

LAPORAN PERKEMBANGAN ANAK Tampilan seperti ini ditemukan untuk 6 aspek perkembangan anak untuk menuliskan narasi perkembangannya. Pada bagian ini terdapat button home untuk kembali ke beranda dan input laporan perkembangan anak. Di dalamnya selain dapat mengisikan narasi perkembangan anak, guru dapat menuliskan rekomendasi atau catatan untuk orangtua terkait perkembangan dan sebuah foto yang mewakili perkembangan anak pada aspek terkait.

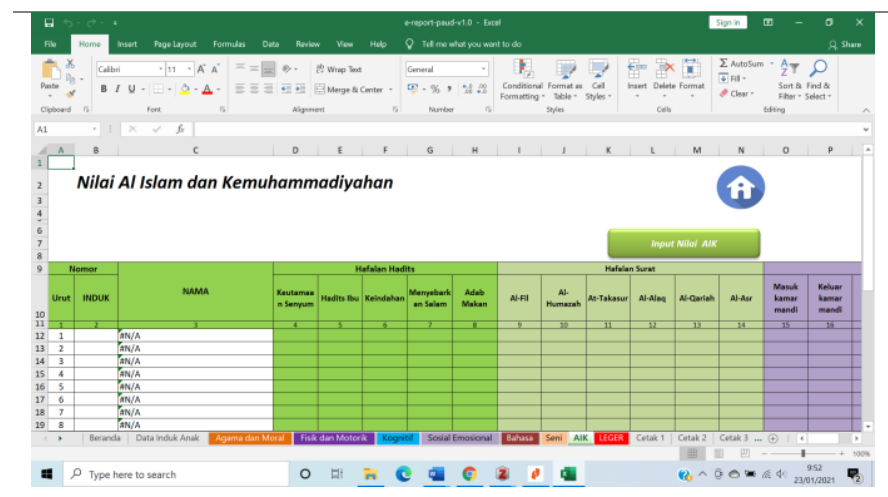

\section{PERKEMBANGAN AIK}

Nilai Al Islam dan Kemuhammadiyahan merupakan bagian untuk melaporakan perkembangan muatan AIK anak didik. Pada bagian ini juga ada tombol home dan tombol input nilai AIK. Muatan materi di dalamnya telah disesuaikan dengan muatan materi AIK yang berlaku di PAUD Aisyiyah. Guru dapat input datanya sesuai kurikulum yang ditetapkan pada semester terkait. 


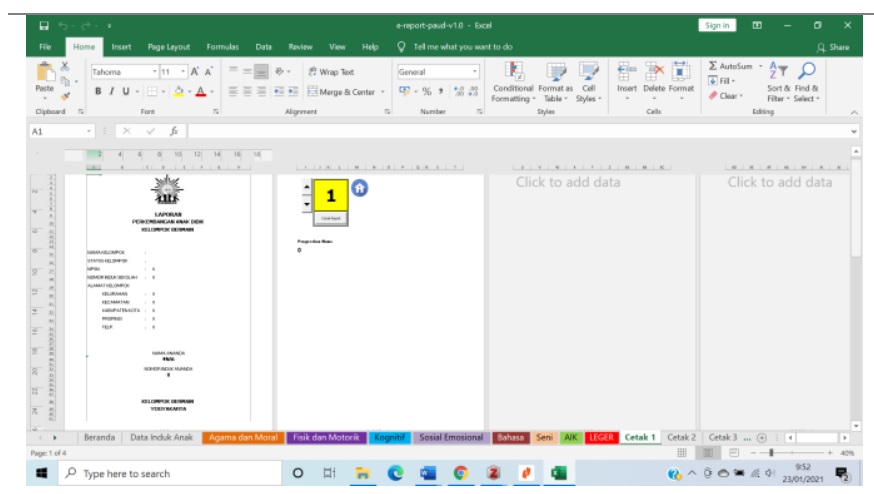

\section{CETAK 1}

Cetak 1 merupakan bagian untuk melakukan pencetakan cover laporan perkembangan anak. Telah tersedia logo dan akan muncul identitas lembaga yang telah diisikan di awal pada bagian ini. Ukuran kertas telah disetting dan disesuaikan dengan ukuran kertas yang digunakan oleh PAUD Aisyiyah se Indonesia.

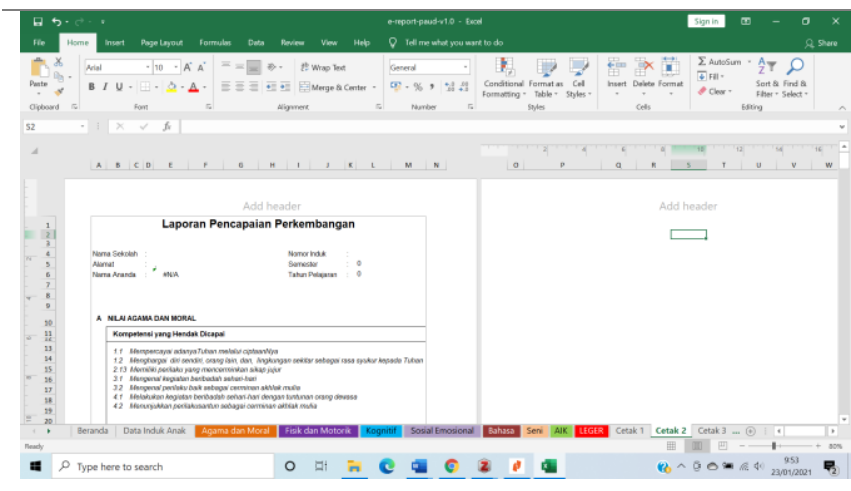

\section{CETAK 2}

Pada bagian cetak 2 ini berisi tentang halaman laporan pencapaian perkembangan anak pada seluruh aspek perkembangan sesuai kurikulum 2013 PAUD. Halaman ini menyajikan ruang deskripsi perkembangan anak dan rekomendasi apa yang bisa dilakukan orangtua bersama guru pada pembelajaran berikutnya yang tekah diinput pada menu input sebelumnya.

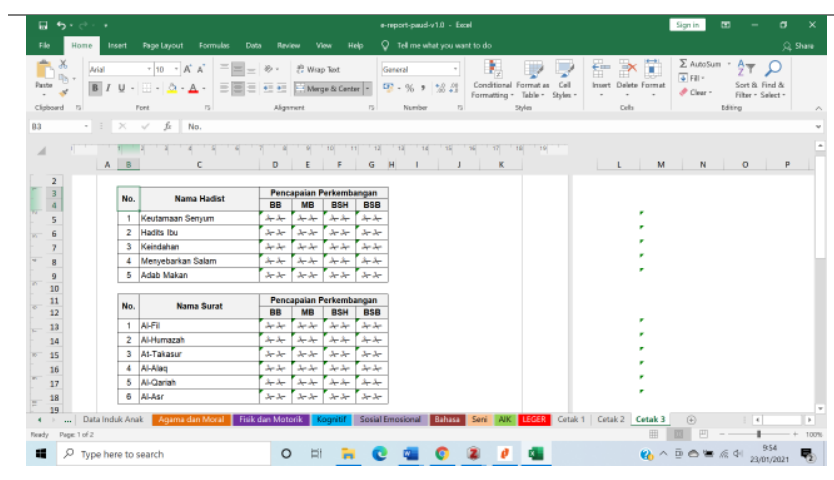

\section{CETAK 3}

Pada bagian cetak 3 berisi tentang penilaian terhadap pencapaian peserta didik terhadap muatan Al Islam dan Kemuhammadiyahan yang telah ditetapkan dalam kurikulum dan telah diinput sebelumnya melalui menu input. Ada skala 4 capaian yang digunakan, yaitu BB (Belum Berkembang), MB (Mulai Berkembang, BSH (Berkembang Sesuai Harapan), dan BSB (Berkembang Sangat Baik). 